\title{
NOTE
}

\section{Occurrence of an algal bloom under Arctic pack ice}

\author{
R. Gradinger* \\ Institut für Polarökologie, Wischhofstraße 1-3, Gebäude 12, D-24148 Kiel, Germany
}

\begin{abstract}
Summer melting of sea ice leads to the formation of under-1ce melt ponds in Arctic seas. The biological characteristics of such a pond were studied in summer 1993. The chlorophyte Pyramimonas sp. (Prasinophyceae) formed a unialgal bloom with cell densities of $19.1 \times 10^{3}$ cells $\mathrm{ml}^{-1}$ and a pigment concentration of $29.6 \mathrm{mg} \mathrm{m}^{-3}$ A comparison with ice core data revealed differences in algal biomass and community structure. Physical data indicate that under-ice ponds are a common feature in the Arctic Ocean. Thus, communities within under-ice ponds, which have not been included in production estimates, may significantly contribute to the Arctic marine food web.
\end{abstract}

KEY WORDS: Arctic Sea ice biota. Phytoplankton Chlorophyll. Under-ice pond Pyramimonas

The development of algal blooms in the Arctic Ocean is largely controlled by the unique environmental conditions in this area. Low water temperature, the dark polar winter and a permanent ice cover severely limit biological production. Thus, the Arctic was considered to be one of the most oligotrophic oceans of the world (Platt \& Subba Rao 1975). Nevertheless, considerable algal biomass can accumulate, at least for periods of weeks, in 3 Arctic marine habitats: (1) inside the sea ice (Horner 1990), (2) in polynyas and (3) in marginal ice zones (e.g. Gradinger \& Baumann 1991). The algal communities forming these 'blooms' are usually dominated by diatoms (Smith \& Sakshaug 1990). Under the permanent ice cover, algal biomass remains low during the entire growth season with flagellates as dominating primary producers (Braarud 1935, Horner \& Schrader 1982). During summer 1993, we surpris. ingly encountered an algal bloom immediately below the sea ice. This note presents our observations on this phenomenon, discussing its possible significance for the Arctic marine system.

•E-mail: npf06@irzuni-kiel.d400.de
Materials and methods. The investigation was conducted during the RV 'Polarstern' expedition ARK IX/4 from August to October 1993. Sampling of ice cores and under-ice water took place at Stns (station number $=$ day of the year $) 230\left(82^{\circ} 45.4^{\prime} \mathrm{N}, 40^{\circ} 12.2^{\prime} \mathrm{E}\right)$ and 231 $\left(82^{\circ} 23.2^{\prime} \mathrm{N}, 40^{\circ} 54.9^{\prime} \mathrm{E}\right)$ At Stn 230 , ice was collected from a $2 \mathrm{~m}$ thick multi-year ice floe. At Stn 231, we encountered a layer of thin ice (grey ice of 21 to $60 \mathrm{~cm}$ thickness) between 2 multi-year ice floes, which were more than $4 \mathrm{~m}$ thick (Fig. 1) Ice cores were taken at both stations with a $7.5 \mathrm{~cm}$ SIPRE ice auger. Under-ice water was collected at Stn 231 from inside the core hole following removal of the core. The ice cores were cut into 2 to $20 \mathrm{~cm}$ long sections to analyse the vertical distribution of ice organisms and algal pigments within the ice. The concentration of algal pigments (chlorophyll $a+$ phaeopigments) was measured on ice samples that were melted directly. The determination was done fluorometrically according to Evans et al. (1987) after filtration on Whatman GF/F filters. For the determination of algal abundances, ice samples were melted in $0.2 \mu \mathrm{m}$ filtered sea water (for details see Gradinger et al. 1991) and filtered onto $0.2 \mu \mathrm{m}$ Nuclepore filters. Species abundances were determined using epifluorescence microscopy after DAPI staining (Porter \& Feig 1980). The Prasinophyte species Pyramimonas sp. was identified by $\mathrm{H}$. A. Thomsen (Botanical Institute, Dept. Phycology, University Copenhagen). Morphometric data of algal species were obtained from fixed material ( $1 \%$ formaldehyde final concentration) using a video image system (Leica Q500MC) attached to a Zeiss Axiovert 135 inverted microscope. Salinity was measured with a WTW LF 191 conductometer

Results. The ice thickness at Stn 231 varied between 0.2 and more than $4 \mathrm{~m}$ (Fig 1). Under-ice video observations through the core holes ( $M$. Poltermann pers. comm.) revealed an approximately $1 \mathrm{~m}$ thick layer of greenish coloured water just below the young ice. The 


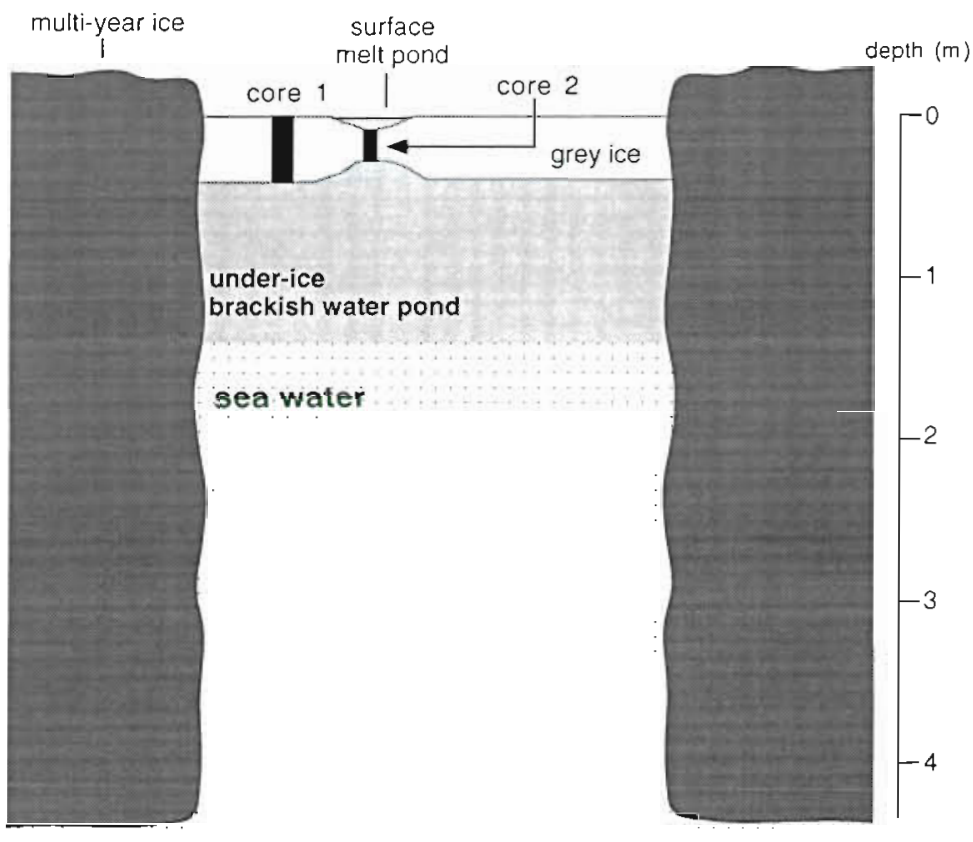

Fig. 1. Ice situation at Stn 231

salinity of this under-ice pond was 9.1 psu. A sharp pycnocline between this pond and the clear water below could be easily seen by video

Algal pigment concentration (Fig 2) was highest in the under-ice brackish water pond (UBP) at $29.6 \mathrm{mg}$ $\mathrm{m}^{-3}$. Sharp gradients were observed inside the ice cores from Stns 231 and 230. Algal pigment concentrations greater than $10 \mathrm{mg} \mathrm{m}^{-3}$ were restricted to the lowermost $10 \mathrm{~cm}$ of the cores (Fig. 2). Almost no phaeopigments were detected in the ice samples, while they contributed $63 \%$ to total algal pigments in the UBP. Large differences were evident in the algal composition of the samples (Fig. 3). Pennate diatoms contributed between 9 and $32 \%$ of all algal cells in the bottom $2 \mathrm{~cm}$ of the ice cores. The algal community in the UBP consisted almost entirely of a single type of phototrophic flagellate. The relative contribution of pennate diatoms to the UBP community was insignificant $(3 \%)$. Centric diatoms were only observed in the 2 ice cores collected at Stn 231 and contributed less than $6 \%$ to total algal abundance.

Microscopical observations of living material on board 'Polarstern' showed that the phototrophic protist (Fig, 4) belonged to the chlorophytes. The cells were characterised by 4 flagella, a cup-shaped chloroplast, a pyrenoid and an eye spot. The species was later identified by electron microscopy as Pyramimonas sp. (H. A. Thomsen pers. comm.). Its maximum size varied between 4 and $16 \mu \mathrm{m}$. In addition to this alga, phototrophic euglenophytes $\left(<1\right.$ cell $\left.\mathrm{ml}^{-1}\right)$, heterotrophic flagellates $\left(4360\right.$ cells $\left.\mathrm{ml}^{-1}\right)$ and bacteria $(2.21 \times$
$10^{6}$ cells $\mathrm{ml}^{-1}$ ) were detected in the UBP sample by epifluorescence microscopy. A large fraction of the heterotrophic flagellates of the size class 10 to $20 \mu \mathrm{m}(61 \%$ of all heterotrophic protists) contained ingested chlorophytes

Discussion. The sea ice cover of the Arctic Ocean has attracted increasing interest from marine biologists over the last decades (see Horner 1985 for a review). Today, it is well known that algae occur in high concentrations in the lowermost decimetres of the ice floes, close to the ice-ocean interface, and contribute substantially to total primary productivity of the Arctic (Legendre et al. 1992).

The high ice algal biomass is used by a variety of animals, which either live permanently on the underside of the sea ice (Carey 1985, Lonne \& Gulliksen 1991) or migrate for parts of their life cycle into the ice-ocean interface (Runge et al. 1991). No direct measurements were available until

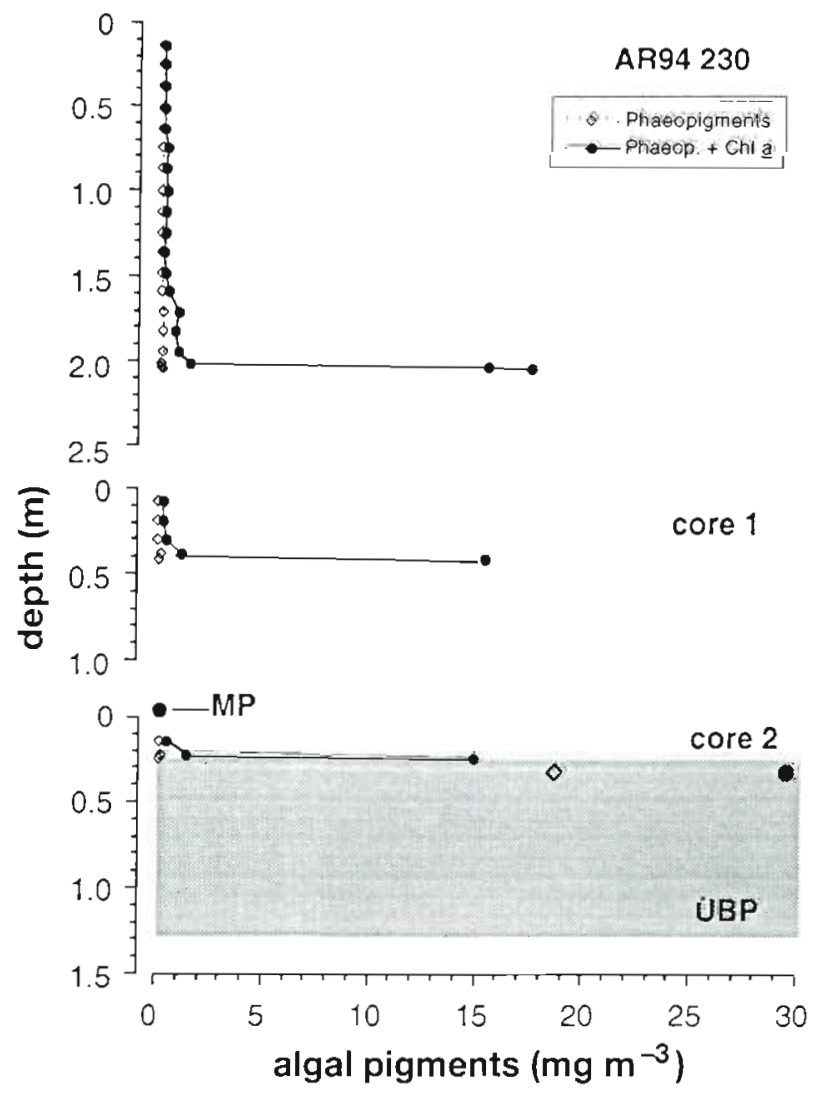

Fig. 2. Phaeopigment and total algal pigment (chlorophyll $a+$ phaeopigments) concentrations in the surface melt pond (MP), sea ice and under ice pond (UBP) at Stns 230 and 231 (core 1 and core 2) 


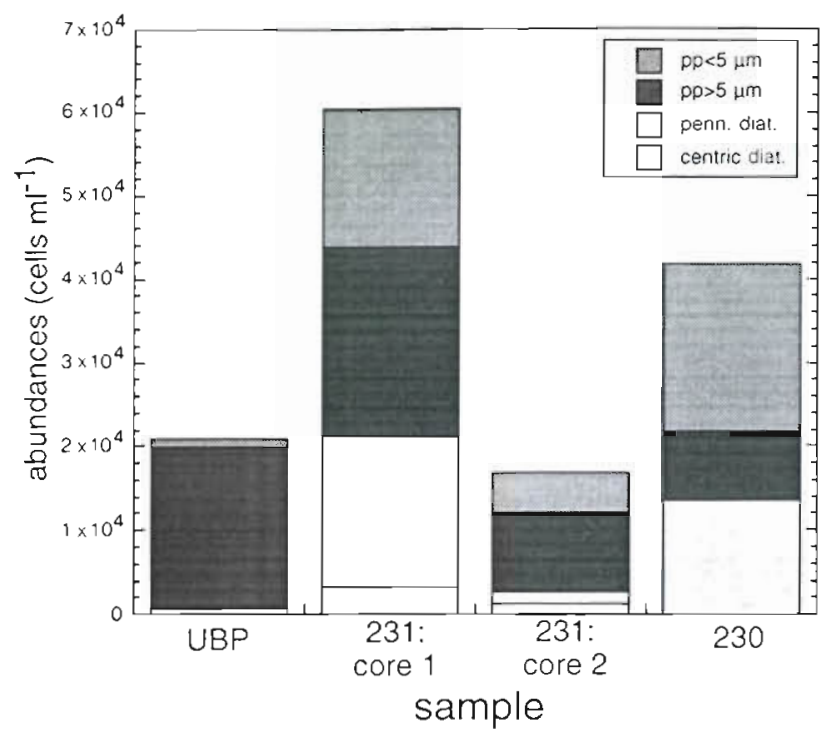

Fig. 3. Composition and abundance of phototrophic cells (penn diat.: pennate diatoms; pp: phototrophic protists other than diatoms) in the under-ice brackish water pond (UBP) and the bottom $2 \mathrm{~cm}$ of the sea ice at Stns 230 and 231

now on the biology of under-ice melt ponds, but Apollonio (1985) summarised the evidence for the existence of a so-called 'halocline flora'. This algal community is characteristic for the upper $2 \mathrm{~m}$ of Arctic waters after

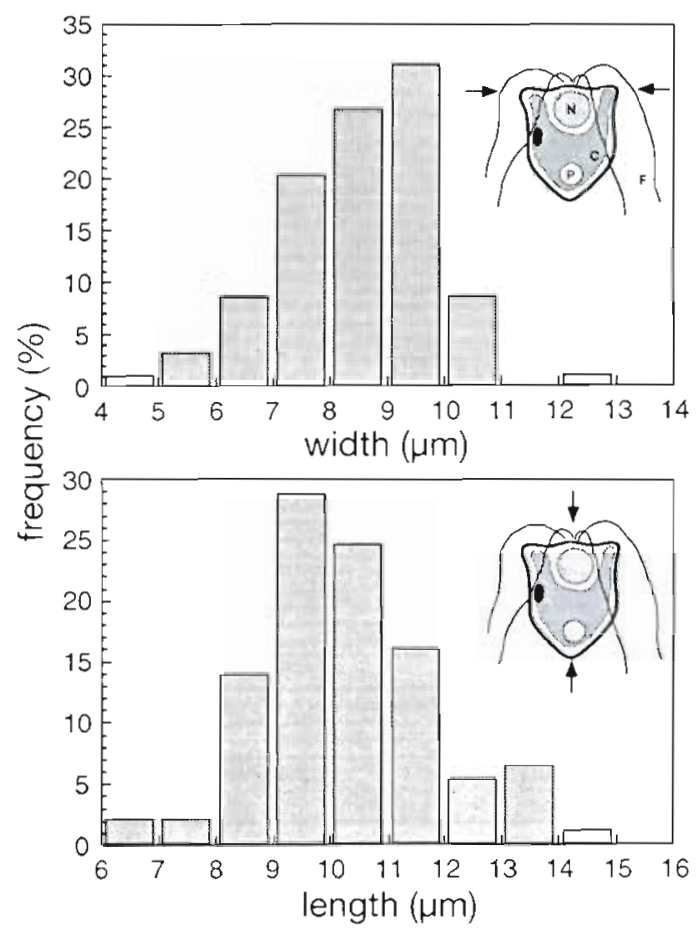

Fig. 4. Size spectra of the chlorophyte observed in the under-ice pond at Stn 231 Cellular structure based on observations of living cells: (S) stigma; (N) nucleus; (C) chloroplast; (P) pyrenoid;

(F) flagella. Arrows indicate location of measurements the summer melt of sea ice and occurs at a constant biomass level of 1 to $2 \mathrm{mg} \mathrm{chl} \mathrm{a} \mathrm{m}^{-3}$ for periods of 6 to 8 wk. Observations by Bursa (1963) suggest that the halocline flora is dominated by phototrophic flagellates (Chlorophyceae and Chrysophyceae) similar to our UBP resuits, but with a different species composition (Chlorella sp., Oocystis sp., Scenedesmus bijugatus, and Ochromonas sp.). Thus, distinct differences exist between the halocline flora and the 'under-ice pond flora' in terms of biomass and species composition. Consequently, the under-ice pond algae represent a fourth type of algal community of the Arctic Ocean, in addition to ice algae, phytoplankton and halocline flora.

Eicken (1994) summarised our present knowledge on under-ice ponds in the context of their distribution and impact on ice morphology. He stated that underice ponds influence the exchange rates between ice and the water column by enhanced desalination, sealing of the ice bottom, and topographic smoothing of the ice bottom. He estimated that the under-ice ponds could cover at least $5 \%$ of the total ice area of the Arctic. No such estimates are available for their occurrence under refrozen leads. Wadhams (1994) showed that refrozen leads, characterised by an ice thickness of less than $1 \mathrm{~m}$, contribute between $4 \%$ (October 1976) and 8 to $16 \%$ (May 1987) of the total ice coverage. Thus, refrozen leads are an important structural component of the Arctic sea ice zone. Therefore, under-ice ponds as observed in this study may be a common feature of the Arctic seas. Further evidence to support this idea is the observation of greenish coloured water flooding over ice floes while RV 'Polarstern' was cruising through the ice at several locations along the cruise track.

For an interpretation of our biological observations, the major factors controlling algal development in icecovered waters, i.e. irradiance and water column stability, have to be taken into account. The light climate in polar waters is highly variable due to the existence of the ice cover. The surface albedo of ice floes ranges from less than 0.3 for ice floes covered with melt ponds to more than 0.8 for snow-covered ice (Maykut 1985). Assuming a $30 \mathrm{~cm}$ thick first year ice without snow cover, as observed at $\operatorname{Stn} 231$, about $4 \%$ of the surface photosynthetically active radiation will reach phytoplankton cells in an under-ice pond, which is about 4 times more than under $2 \mathrm{~m}$ thick ice (Maykut \& Grenfell 1975). Hence, the light climate of an under-ice pond in a refrozen lead is more likely to favour algal growth compared to the water column or ponds under multi-year ice with a mean draft of more than $2 \mathrm{~m}$. The high irradiance and vertical stability due to the low salinity within the under-ice pond allow the formation of an algal bloom of similar magnitude as observed in marginal ice zones or polynyas (Table 1). 
Table 1 Algal biomass ( $\mathrm{mg} \mathrm{chl}$ a) in various habitats of the Arctic

\begin{tabular}{|ccccc}
\hline Biomass & Polynya $^{\text {a }}$ & $\begin{array}{c}\text { Ice-covered } \\
\text { water }\end{array}$ & $\begin{array}{c}\text { Marginal } \\
\text { ice }^{\mathrm{a}} \text { zone }\end{array}$ & $\begin{array}{c}\text { Under-ice } \\
\text { pond }\end{array}$ \\
\hline $\mathrm{Chla} \mathrm{m}-2$ & 58 & 7 & 55 & $11^{b}$ \\
$\mathrm{Chla} \mathrm{\textrm {m } ^ { - 3 }}$ & 1.5 & 0.2 & 1.4 & 11.0
\end{tabular}

"Data from Gradinger \& Baumann (1991) represent integrals (upper values) and means (lower values) for the upper $40 \mathrm{~m}$ of the water column in the ice-covered East Greenland Current

Integrated over $1 \mathrm{~m}$ thickness

The specific environmental conditions inside the under-ice pond are reflected in the formation of a unique community structure, dominated by Pyramimonas sp. Salinity greatly affects species distributions, with low salinity brackish water habitats containing the lowest diversity of phyto- and zooplankton species (Krey 1974). Therefore, the low salinity of 9.1 psu is probably responsible for the dominance of Pyramimonassp., in contrast to the relevance of diatoms inside the sea ice. The occurrence of bacteria and of protozoa, which contained ingested chlorophytes, indicate that an active microbial food web was present within the under-ice pond.

The high phaeopigment concentrations in the underice pond probably cannot be attributed to protozoa, as these organisms do not significantly contribute to the production of chiorophyll breakdown products (Barlow et al. 1988). Therefore, other processes, e.g. meso- and macrozooplankton grazing (Welschmeyer \& Lorenzen 1985) or pigment damage due to high light intensities, might be responsible for our observation. At present, we do not know whether grazers such as amphipods and herbivorous copepods are able to use the high algal biomass. The low salinity of the under-ice pond may act to exclude the marine herbivores. Thus, the pigment composition in the UBP remains enigmatic and cannot be explained with the available data. Future studies by phyto-and zooplanktologists should therefore include research on processes occurring in the interface of ice and the water column in various regions and habitats, i.e. leads, refrozen leads and under thicker ice floes, which might represent spots of high primary productivity which have so far been neglected in the estimates by Legendre et al. (1992) and Subba Rao \& Platt (1984). New studies should try to integrate coupling processes between ice, under-ice ponds and the water column in this highly structured environment on vertical scales of centimetres to decimetres below the ice floes.

Acknowledgements. The ongoing helpfulness of the crew of RV 'Polarstern' is gratefully acknowledged. I thank my colleagues $H$. Eicken, C. Friedrich, R. Pac, M. Poltermann,
E. Reimnitz, and J. Weissenberger for assistance at the ice stations and during the sample treatments. Comments and discussions with many members of the Institute of Polar Ecology helped to improve this manuscript. I am grateful to $\mathrm{H}$. A. Thomsen for identification of Pyramimonas sp. The critical comments of 3 anonymous referees significantly improved the manuscript. This study was supported by the Deutsche Forschungsgemeinschaft (DFG Gr 1405/1-1) and the Commission of the European Communty under contract MAS2-CT93-0057 of the MAST-II programme

\section{LITERATURE CITED}

Apollonio S (1985) Arctic marine phototrophic systems: functions of sea ice stabilisation. Arctic 38:167-173

Barlow RG, Burkill PH, Mantoura RFC (1988) Grazıng and degradation of algal pigments by marine protozoan Oxyrrhis marina. J exp mar Biol Ecol 119:119-129

Braarud T (1935) The 'Ost'-expedition to the Denmark Strait 1929: 2. The phytoplankton and its conditions of growth. Hvalradets Skr 10:1-171.

Bursa A (1963) Phytoplankton in coastal waters of the Arctic Ocean at Point Barrow, Alaska. Arctic 16:239-262

Carey AG (1985) Marine ice fauna: Arctic. In: Horner R (ed) Sea ice biota. CRC Press, Boca Raton, p 173-190

Eicken $\mathrm{H}$ (1994) Structure of under-ice melt ponds in the central Arctic and their effect on the sea-ice cover Limnol Oceanogr 39:682-694

Evans CA, O'Reilly JE, Thomas JP (1987) A handbook for the measurement of chlorophyll $a$ and primary production. SCAR Biomass Res Ser Handbook 8:1-114

Gradinger RR, Baumann MEM (1991) Distribution of phytoplankton communities in relation to large-scale hydrographical regime in the Fram Strait. Mar Biol 111:311-321

Gradinger R, Spindler M. Henschel D (1991) Development of Arctic sea-ice organisms under graded snow cover. Polar Res 10:295-308

Horner R (1985) Sea ice biota. CRC Press, Boca Raton

Horner R (1990) Ice-associated ecosystems. In: Medlin LK, Priddle $J$ (eds) Polar marine diatoms. British Antarctic Survey, Cambridge, p 9-14

Horner R, Schrader GC (1982) Relative contribution of ice algae, phytoplankton, and benthic microalgae to primary production in nearshore regions of the Beaufort Sea. Arctic 35:485-503

Krey J (1974) Das Plankton. In: Magaard L, Rheinheimer G (eds) Meereskunde der Ostsee. Springer-Verlag, Berlin, p 103-130

Legendre L, Ackley SF, Dieckmann GS, Gulliksen B, Horner R, Hoshiai T, Melnikov IA, Reeburgh WS, Spindler M, Sullivan CW (1992) Ecology of sea jce biota. 2. Global significance. Polar Biol 12:429-444

Lønne OJ, Gulliksen B (1991) On the distribution of sympagic macro-fauna in the seasonally ice covered Barents Sea. Polar Biol 11:457-469

Maykut GA (1985) The ice environment. In: Horner R (ed) Sea ice biota. CRC Press, Boca Raton, p 21-82

Maykut GA, Grenfell TC (1975) The spectral distribution of light beneath first-year sea ice in the Arctic Ocean. Limnol Oceanogr 20:554-563

Platt T, Subba Rao V (1975) Primary production of marine microphytes. In: Cooper JP (ed) Photosynthesis and productivity of different environments. Cambridge Univ Press, Cambridge, p 249-280

Porter KG, Feig YS (1980) The use of DAPI for identifying and counting aquatic microflora. Limnol Oceanogr 25:943-948 
Runge JA, Therriault $J$, Legendre $L$, Ingram $R G$, Demers $S$ (1991) Coupling between ice microalgal productivity and the pelagic, metazoan food web in southeastern Hudson Bay: a synthesis of results. Polar Rec 10:325-338

Smith WO Jr, Sakshaug E (1990) Polar phytoplankton. In: Smith WO Jr (ed) Polar oceanography. Part B. Chemistry, biology and geology. Academic Press, San Diego, p 477-525 Subba Rao DV, Platt T (1984) Primary production of Arctic waters. Polar Biol 3:191-201

This note was submitted to the editor
Wadhams P (1994) Sea ice thickness changes and their relation to climate. In: Johannessen OM, Muench $\mathrm{RD}$, Overland JE (eds) The polar oceans and their role in shaping the global environment. AGU, Washington, p 337-361

Welschmeyer NA, Lorenzen CJ (1985) Chlorophyll budgets: zooplankton grazing and phytoplankton growth in a temperate fjord and the central Pacific Gyres. Limnol Oceanogr 30:1-21

Manuscript first received: June 13,1995

Revised version accepted: September 14, 1995 